\title{
EFISIENSI PEMASARAN BUAH JAMBLANG (Syzygium cumini (L) Skeels) (STUDI KASUS DI DESA TRIWIDADI, KECAMATAN PAJANGAN, KABUPATEN BANTUL, PROVINSI YOGYAKARTA)
}

\author{
Marketing Efficiency of Jamblang Fruits (Syzygium cumini (L) Skeels) (Case Study in \\ Triwidadi Village, Pajangan Subdistrict, Bantul District, Yogyakarta)
}

\author{
Soleh Mulyana, Suhartono dan Aris Sudomo \\ Balai Penelitian dan Pengembangan Teknologi Agroforestry \\ Jl. Raya Ciamis-Banjar Km 4 Ciamis 46201 Tlp. (0265)771352 Fax (0265) 775866 \\ e-mail: solehmulyana@yahoo.co.id, om_hartono@yahoo.com*, arisbpkc@gmail.com
}

Diterima 23 Januari 2019, direvisi 24 Mei 2019, disetujui 9 Juli 2019

\begin{abstract}
Jamblang is one of multipurpose tree species especially utilised for medical purposes. However, population of jamblang tree on private land in Bantul district is still limited because of less information on jamblang's advantage value and its silvicultural technique. The objective of the research is to find out the marketing flow and the efficiency of jamblang fruit in Triwidadi Village, Pajangan Sub District, Bantul District of Yogyakarta. The Data was collected by interviewing 15 farmers who owned jamblang trees, 1distributor and 1 retailer using snowball method. The research shows that marketing flow of jamblang should contain several marketing institutions i.e : producer/farmers, collector, retailer and customer through 3 models of marketing flow. In first model of marketing flow, farmers sell un-harvested jamblang fruit (still on the tree) to the collectors, then the collectors sell it to the retailer and the retailer sell it to the customer. In the second method, farmers sell the harvested jamblang fruit to the collectors to be continued to the retailer and then the customer. Meanwhile, in the third marketing flow, farmers sell the harvested jamblang fruit directly to the retailer to be continued to the last customers. Marketing system of jamblang throughsecond and third method is more efficient then the first marketing because the methods have lower margin (Rp $2500 / \mathrm{kg}$ ) and farmer's share more than $50 \%$ (58.33\%).
\end{abstract}

Keyword : marketing efficiency, jamblang, margin of distribution

\begin{abstract}
ABSTRAK
Jamblang adalah salah satu jenis tanaman serba guna yang memiliki banyak manfaat terutama untuk obat-obatan. Namun demikian, populasi tanaman jamblang pada lahan masyarakat di wilayah Kabupaten Bantul masih terbatas. Penelitian ini bertujuan untuk mengetahui saluran dan efisiensi pemasaran buah jamblang di Desa Triwidadi, Kecamatan Pajangan, Kabupaten Bantul, Daerah Istimewa Yogyakarta. Penelitian dilakukan dengan metode survei terhadap petani pemilik tanaman jamblang dan pedagang yang terlibat dalam pemasaran buah. Pengumpulan data dilakukan dengan wawancara terhadap 15 orang petani pemilik tanaman jamblang yang dipilih berdasarkan sensus serta 1 pedagang pengepul dan 1 pedagang pengecer yang dipilih secara snowball. Data hasil wawancara dianalisis secara deskriptif, sedangkan efisiensi sistem pemasaran dianalisis berdasarkan margin pemasaran dan farmer`s share. Hasil penelitian menunjukkan bahwa saluran pemasaran buah jamblang terlaksana dengan melibatkan beberapa lembaga pemasaran seperti produsen, pengepul, pengecer dan konsumen akhir melalui 3 model saluran pemasaran. Pada model saluran pemasaran 1 petani menjual buah jamblang masih di atas pohon kepada pengepul, kemudian pengepul menjual kepada pedang pengecer dan berlanjut ke konsumen akhir. Sementara pada saluran pemasaran 2 petani menjual buah jamblang yang telah dipanen kepada pedagang pengepul kemudian diteruskan ke pedagang pengecer sampai konsumen akhir. Sedangkan pada saluran pemasaran 3 petani menjual langsung hasil panen buah jamblang kepada pedagang pengecer dan diteruskan ke konsumen akhir. Sistem pemasaran buah jamblang melalui saluran pemasaran 2 dan 3 lebih efisien dari saluran pemasaran 1 karena memiliki margin yang lebih rendah, yaitu Rp 2.500/kg dan nilai farmer's share yang lebih tinggi, yaitu $58,33 \%(>50 \%)$.
\end{abstract}

Kata Kunci : efisiensi pemasaran, jamblang dan saluran pemasaran 


\section{PENDAHULUAN}

Jamblang (Syzygium cumini Linn.) merupakan salah satu jenis tanaman serbaguna yang dikenal oleh masyarakat sebatas sebagai penghasil buah. Selain untuk dikonsumsi, beberapa bagian tanaman jamblang memiliki potensi untuk dimanfaatkan sebagai obat-obatan. Beberapa hasil penelitian menyatakan bahwa bagian tanaman jamblang memiliki manfaat kesehatan antara lain daunnya dapat membantu menghambat pertumbuhan bakteri E. coli dan S. Aureus, zat antioksidan, anti implamasi dan menurunkan kadar glukosa dalam darah (Sudarmi, Darmayasa, \& Muksi, 2017; Sami, Nur, Kursia, Gani, \& Sidupa, 2017; Dewi, 2018; Raya, Ngardita, \& Sumardi, 2018; Indrisari \& Zulham, 2018); kulit buahnya mengandung zat antioksidan dan anti jamur (Thomson, Anggraini, Kurniawan, Yenrina, \& Sayuti, 2018; Chismirina, Rezeki, \& Rusiwan, 2014), dan ekstrak bijinya sebagai obat alternatif untuk membantu penyembuhan luka diabetes (Lissa, Ratnasari, \& Luzyawati, 2018; Kumar et al., 2013; Ayyanar, Subash-Babu, \& Ignacimuthu, 2013). Selain untuk keperluan obat, bagian kulit buah jamblang juga dapat dimanfaatkan untuk pewarna alami kosmetik (Sari, 2013).

Populasi tanaman jamblang di Daerah Istimewa Yogyakarta masih terbatas karena upaya budidaya belum banyak dilakukan dan nilai ekonomi tanaman yang memiliki manfaat kesehatan ini belum banyak diketahui. Namun demikian di Desa Triwidadi, Kecamatan Pajangan, Kabupaten Bantul, Daerah Istimewa Yogyakarta, masih ada sebagian masyarakat memiliki hutan rakyat jamblang. Hutan rakyat jamblang tersebut dapat menghasilkan buah yang bisa dikonsumsi dan dipasarkan masyarakat sebagai bahan makanan.

Ketersediaan pasar produksi buah jamblang sangat penting agar mendorong masyarakat untuk membudidayakannya di lahan hutan rakyat. Mengingat tanaman
Jamblang berbuah setahun sekali dan produksi buah jamblang yang tidak dapat disimpan dalam waktu lama sehingga harus segera didistribusikan dalam saluran pemasaran. Dalam hal ini, peran lembaga perantara dalam pemasaran buah jamblang sangat membantu petani dalam memasarkan produknya. Namun sebaliknya, apabila proses distribusi terlalu panjang dapat merugikan petani. Oleh karena itu saluran pemasaran sangat penting bagi petani jamblang karena selain menjadi sarana untuk menjual produk, juga akan membantu kelancaran informasi pasar dari produsen kepada konsumen.

Selain adanya ketersediaan pasar, pemilihan saluran pemasaran yang tepat dapat membantu petani untuk mendapatkan bagian harga yang menguntungkan. Penelitian Hikmah, Nurchayati, \& Ratnawati (2015) dan Permadi (2017) menjelaskan bahwa saluran pemasaran yang pendek dapat memberikan keadilan yang lebih baik kepada produsen (petani) karena tercapainya efisiensi teknis pemasaran yang semakin tinggi. Penelitian ini bertujuan untuk mengetahui saluran dan efisiensi pemasaran buah jamblang hasil panen dari hutan rakyat di Desa Triwidadi, Kecamatan Pajangan, Kabupaten Bantul, Provinsi Daerah Istimewa Yogyakarta.

\section{METODE PENELITIAN}

Kajian pemasaran buah jamblang dilaksanakan di Desa Triwidadi, Kecamatan Pajangan Kabupaten Bantul, Provinsi Yogyakarta. Pengumpulan data dilakukan pada Bulan Maret 2018 dengan metode wawancara terhadap 15 orang petani pemilik pohon jamblang, 1 pedagang pengepul dan 1 pedagang pengecer. Pemilihan responden petani jamblang dilakukan secara sensus, sedangkan responden pedagang dipilih secara snowball. Berdasarkan informasi awal dari petani responden dilakukan penelusuran aliran produksi buah jamblang melalui lembaga-lembaga pemasaran yang terbentuk sampai kepada konsumen akhir. 
Jenis data yang dikumpulkan antara lain harga buah jamblang pada tingkat petani, biaya pemasaran, keuntungan dan harga penjualan setiap lembaga pemasaran serta harga yang dibayarkan oleh konsumen akhir. Selanjutnya untuk menentukan efisiensi sistem pemasaran dilakukan analisis margin pemasaran dan nilai tukar/harga petani dengan pendekatan matematis (Soekartawi, 2002) sebagaimana telah digunakan dalam penelitian bidang ekonomi pertanian oleh Pradika, Hasyim, \& Soelaiman (2013), Rahim (2013), dan Surahman \& Kusnadi (2017) dengan rumus berikut:

$\mathrm{Mp}=\mathrm{Pr}-\mathrm{Pf}$ dan $\mathrm{Fs}=(\mathrm{Pf} / \mathrm{Pr}) \times 100 \%$

\section{Dimana:}

$\mathrm{Mp}=$ marjin pemasaran; $\mathrm{Fs}=$ farmers share; $\mathrm{Pr}=$ harga di tingkat konsumen; $\mathrm{Pf}=$ harga ditingkat produsen.

Selanjutnya dihitung pula margin keuntungan pemasaran pada masing-masing lembaga pemasaran dengan formulasi sebagai berikut (Angipora, 2002) :

$\pi=\mathrm{MP}-\mathrm{TC}$

keterangan: $\pi=$ keuntungan di tingkat lembaga pemasaran; MP = Marjin pemasaran di tingkat lembaga pemasaran; $\mathrm{TC}=$ total biaya di tingkat lembaga pemasaran.

Sistem pemasaran dikategorikan efisien apabila tercipta keadilan bagi kedua belah pihak yaitu petani dan konsumen (Irawan, 2007). Petani mendapatkan harga yang tinggi sedangkan konsumen mendapatkan harga yang rendah. Hal ini dapat tercapai apabila margin pemasaran yang kecil dan proporsi harga yang diterima petani yang besar. Menurut Soekartawi (2002), pemasaran dikatakan efisien apabila bagian harga yang diterima petani (farmers share) $>50 \%$.

\section{HASIL DAN PEMBAHASAN}

\section{A. Keadaan Umum dan Potensi Jamblang di Lokasi Penelitian}

Triwidadi merupakan salah satu desa di Kecamatan Pajangan, Kabupaten Bantul, Daerah Istimewa Yogyakarta dengan ketinggian antara 110-300 $\mathrm{m}$ di atas permukaan laut. Berdasarkan informasi dari pemerintah desa, wilayah Desa Triwidadi didominasi oleh dataran dengan suhu rata-rata $28-30^{\circ} \mathrm{C}$. Luas wilayah Desa Triwidadi \pm 430 ha terdiri dari lahan datar \pm 130 ha dan lahan berbukit \pm 300 ha dengan tanah subur 80 ha, sedang \pm 294 ha dan tidak subur \pm 56 ha.

Hutan rakyat jamblang di Desa Triwidadi yang berasal dari permudaan alam semakin lama semakin berkurang. Tuntutan kebutuhan lahan menyebabkan tempat tumbuh jamblang telah beralih fungsi menjadi lahan agroforestri dan sebagian menjadi pemukiman. Hal ini memiliki kesamaan kondisi dengan apa yang terjadi di wilayah Majalengka dimana kelangkaan buah jamblang disebabkan oleh menurunnya populasi tanaman akibat adanya alih fungsi lahan (Mulyana \& Sudomo, 2015).

Berdasarkan hasil observasi lapangan di lokasi penelitian, jamblang banyak tumbuh di lahan hutan rakyat. Tanaman jamblang tumbuh berasosiasi dengan beberapa jenis tanaman tahunan lain seperti akasia, angsana, asem, jati, johar, kelapa, mahoni, mangga dan melinjo. Pertumbuhan pohon jamblang yang ada di Desa Triwidadi relatif lambat dengan penampakan fisik batang yang cenderung bengkok, serta perakaran dan kanopinya menyebar.

Rata-rata pohon jamblang di lokasi penelitian telah berdiameter $\geq 40 \mathrm{~cm}$ dengan potensi menghasilkan buah sebanyak 50-75 $\mathrm{kg} /$ pohon. Salah satu jenis jamblang yang paling banyak dipasarkan di wilayah Kabupaten Bantul dan sekitarnya yaitu jenis gentong dengan ciri khas buahnya memiliki daging yang tebal dan rasa yang lebih manis. 


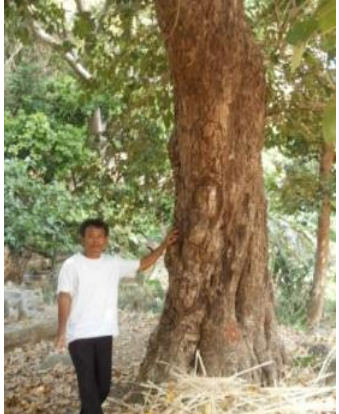

(a)

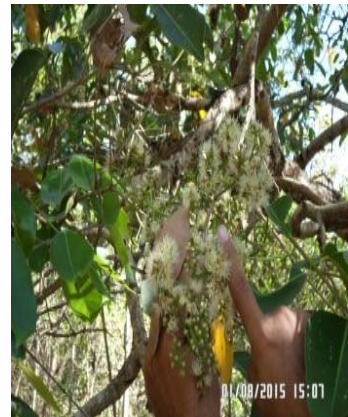

(b)

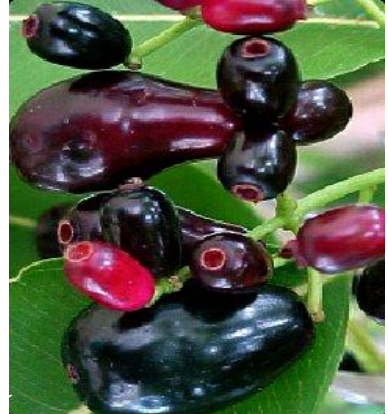

(c)

Keterangan (remarks): a=batang (stem); b=daun dan bunga (leaves and flowers); $\mathrm{c}=\mathrm{buah}$ (fruits)

Gambar 1. Bagian-bagian Tanaman Jamblang

Figure 1. Parts of Jamblang Plants

\section{B. Pemasaran Buah Jamblang}

1. Lembaga dan saluran pemasaran buah jamblang

Buah jamblang berbuah sekali dalam setahun sekitar bulan September-Desember. Pemanfaatan buah jamblang di Yogyakarta adalah sebatas untuk dikonsumsi langsung/makanan. Keberadaan buah yang mulai langka dan rasa yang khas (manis/asam) membuat selalu saja ada yang mencari setiap tahunnya meskipun dengan jumlah relatif terbatas. Berdasarkan hasil survei diperoleh informasi harga dan para pihak yang terlibat dalam tataniaga buah jamblang di wilayah Kabupaten Bantul sebagaimana pada Gambar 2.

Terdapat 2 pola pemasaran yang dilakukan petani yaitu pola 1 (buah jamblang dijual setelah di panen) dan pola 2 (penjualan buah sistem borongan di atas pohon/belum dipanen). Harga buah jamblang pada pola pemasaran 1 adalah Rp 3.500 per kilogram, sedangkan pada pola pemasaran $2 \mathrm{Rp} 1.500$ per kilogram. Buah jamblang dipasarkan melalui tiga jenis saluran pemasaran seperti yang terlihat pada Gambar 1 berikut :

\section{Saluran Pemasaran 1 :}

Petani menjual buah diatas pohon dengan sistem borongan

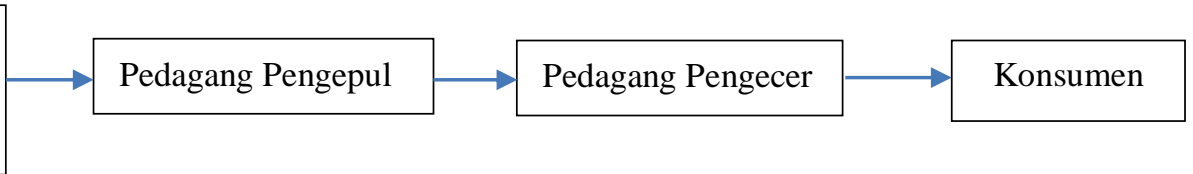

\section{Saluran Pemasaran 2 :}

\section{Petani menjual buah} setelah dipanen

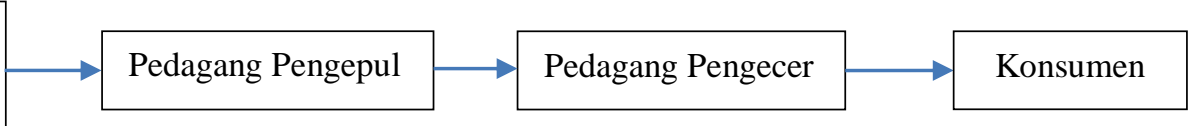

Saluran Pemasaran 3 :

Petani menjual buah setelah dipanen

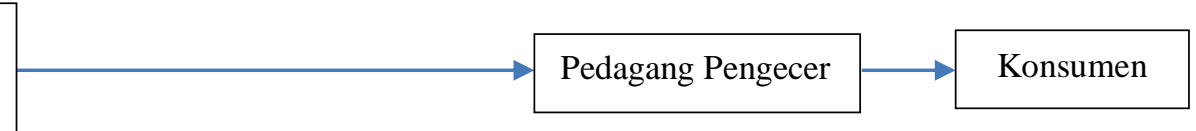

Gambar 2.Saluran Pemasaran Jamblang di Desa Triwidadi Kecamatan Pajangan Kabupaten Bantul Figure 2. Marketing Chanels of Jamblang Fruits in Triwidadi Village, Pajangan Sub District, Bantul District 
Saluran pemasaran buah jamblang di wilayah Kabupaten Bantul hanya melibatkan 3-4 lembaga pemasaran. Hal ini disebabkan produksi dan permintaan buah jamblang yang terbatas. Dengan saluran pemasaran yang pendek ini, buah jamblang yang tidak bisa disimpan lama dapat segera sampai ke tangan konsumen. Pada saluran pemasaran 1 dan 2, lembaga pemasaran yang terlibat adalah petani, pedagang pengepul, pedagang pengecer dan konsumen akhir. Berbeda dengan saluran pemasaran 3 dimana rantai distribusi lebih pendek tanpa melalui pedagang pengepul melainkan hanya 3 lembaga (petani, pedagang pengecer dan konsumen akhir). Pada saluran pemasaran 1, petani menjual buah jamblang dengan sistem tebasan/borongan di atas pohon/tanpa memanen terlebih dahulu. Hal ini menimbulkan adanya oportunity cost yang akan menjadi tambahan pendapatan petani apabila petani memilih memanen buah jamblang terlebih dahulu. Meskipun demikian petani lebih suka menjual diatas pohon karena buah jamblang cepat busuk dan belum ada kepastian dari pembeli/pedagang pengepul/pedagang pengecer yang bersedia membelinya. Petani akan memanen sendiri jika terdapat kepastian permintaan dari pedagang pengepul/pedagang pengecer.

Pada kegiatan pemasaran buah jamblang melalui saluran pemasaran 1 terdapat 2 macam tempat terjadinya transaksi yaitu: (1) pedagang pengecer bisa membeli buah jamblang langsung ke rumah pedagang pengepul; dan (2) pedagang pengepul menjual/mengirim barang di pasar dimana pedagang pengecer berada. Hal ini berimplikasi pada biaya transportasi yang harus dikeluarkan oleh pedagang pengepul atau pengecer. Jika transaksi terjadi di rumah pedagang pengepul maka biaya transportasi ditanggung pedagang pengecer dan begitu juga jika transaksi terjadi di lokasi pedagang pengecer/pasar maka biaya transportasi ditanggung pedagang pengepul. Sementara pada saluran pemasaran 2 dan 3 buah jamblang dipanen terlebih dahulu kemudian baru dijual ke pedagang pengepul ataupun langsung pedagang pengecer yang akan menjualnya di pasar tradisional.

Buah jamblang masih bisa ditemukan di pasar tradisional Kranggan Yogyakarta pada saat musim berbuah. Di pasar tradisional inilah terjadi pertemuan pedagang pengecer dengan konsumen akhir. Rantai pemasaran buah jamblang yang pendek adalah serupa dengan rantai pemasaran komoditas lain seperti semangka di Yogyakarta, cabai merah keriting di Bantul, kapulaga di Pangandaran yang hanya melibatkan 3-4 lembaga pemasaran (Istiyanti, 2010); (Astuti, 2014); (Herliadi, Herdiansyah, \& Ramdan, 2015). Bahkan beberapa tanaman obat (kapulaga, jahe, kencur dan lengkuas) yang ditanam di bawah hutan rakyat juga hanya memiliki saluran pemasaran yang pendek yaitu petani, pengepul tingkat desa, pengepul tingkat kecamatan dan industri/konsumen akhir (Widyaningsih \& Diniyati, 2010). Keuntungan dari rantai pemasaran yang pendek antara lain adalah petani mendapat bagian harga yang lebih besar dan konsumen mendapat harga yang lebih murah dengan kualitas buah yang lebih segar. Selain itu, petani bisa berinteraksi dengan pedagang pengepul dan pedagang pengecer sehingga informasi harga bisa diakses oleh semua pelaku pasar dan tidak terdapat monopoli pasar. Saluran pemasaran komoditas buah yang pendek menguntungkan petani dan konsumen (Hikmah et al., 2015).

2. Biaya dan keuntungan pemasaran buah jamblang

Fungsi-fungsi pemasaran yang dilakukan oleh setiap lembaga bertujuan untuk meningkatkan/mempertahankan nilai kegunaan komoditi sehingga tetap diterima konsumen. Komoditi buah jamblang relatif tidak tahan lama (1-2 hari) dan mudah mengalami kerusakan sehingga pedagang perantara akan berhati hati dalam penanganan buah jamblang. Oleh karena itu dalam proses pengaliran produk dari titik produksi sampai konsumen harus dilakukan secepatnya dan 
tanpa banyak perlakuan perlakuan tambahan. Biaya yang muncul dalam pemasaran buah jamblang adalah biaya pengangkutan dan penyimpanan buah. Pada Tabel 2 disajikan rincian biaya, keuntungan dan persentase keuntungan pemasaran pada setiap lembaga pemasaran.

Tabel 2. Rata-rata biaya dan ratio keuntungan pemasaran per kilogram buah jamblang pada setiap lembaga pemasaran Table 2. Average of cost and profit marketing per kilogram jamblang fruit for each marketing institution

\begin{tabular}{|c|c|c|c|}
\hline \multirow[b]{2}{*}{ Uraian (Description) } & \multicolumn{3}{|c|}{ Saluran Pemasaran (Marketing chanels) } \\
\hline & $\begin{array}{r}\text { Saluran } \\
\text { (chanel ) } 1\end{array}$ & $\begin{array}{r}\text { Saluran } \\
\text { (chanel ) } 2\end{array}$ & $\begin{array}{r}\text { Saluran } \\
\text { (chanel ) } 3\end{array}$ \\
\hline \multicolumn{4}{|l|}{ Petani (Farmers) } \\
\hline Biaya produksi (Production cost) $(\mathrm{Rp})$ & 1.261 & 2.261 & 2.261 \\
\hline Harga penjualan (Sales price) $(\mathrm{Rp})$ & 1.500 & 3.500 & 3.500 \\
\hline Keuntungan petani (Farmers profit)(Rp) & 2.39 & 1.239 & 1.239 \\
\hline Persentase Keuntungan Pemasaran (Percent marketing profit)(\%) & 15,93 & 35,40 & 35,40 \\
\hline \multicolumn{4}{|l|}{ Pengepul (Collectors) } \\
\hline Harga pembelian (Purchase price) (Rp) & 1.500 & 3.500 & - \\
\hline Biaya pemasaran (Marketing cost) (Rp) & 1.500 & 500 & - \\
\hline Harga penjualan (Sales price) $(\mathrm{Rp})$ & 4.500 & 4.500 & - \\
\hline Keuntungan (Marketing profit) $\pi / \mathrm{C}(\mathrm{Rp})$ & 1.500 & 500 & - \\
\hline Persentase Keuntungan Pemasaran (Percent marketing profit)(\%) & 33,33 & 11,11 & - \\
\hline \multicolumn{4}{|l|}{ Pengecer (Retailers) } \\
\hline Harga pembelian (Purchase price) (Rp) & 4.500 & 4.500 & 3.500 \\
\hline Biaya pemasaran (Marketing cost) (Rp) & 60 & 60 & 560 \\
\hline Harga penjualan (Sales price) (Rp) & 6.000 & 6.000 & 6.000 \\
\hline Keuntungan (Marketing profit) $\pi / \mathrm{C}(\mathrm{Rp})$ & 1.440 & 1.440 & 1.940 \\
\hline Persentase Keuntungan Pemasaran (Percent marketing profit)(\%) & 24 & 24,00 & 32,33 \\
\hline \multicolumn{4}{|l|}{ Konsumen (Consumers) } \\
\hline Harga pembelian (Purchase price)(Rp) & 6.000 & 6.000 & 6.000 \\
\hline Tatal Margin Keuntungan (Total profit margin) (Rp) & 3.179 & 3.179 & 3.179 \\
\hline
\end{tabular}

Sumber (Source) : Olah data primer, 2018 (Processed primary data, 2018)

Biaya pemasaran yang dikeluarkan oleh lembaga pemasaran berbeda-beda pada setiap saluran pemasaran. Komponen biaya dalam pemasaran buah jamblang didominasi oleh biaya transportasi. Biaya pemasaran tertinggi dikeluarkan oleh pedagang pengepul pada saluran pemasaran $1 \mathrm{Rp} 1.500 / \mathrm{kg}$ yang terdiri dari biaya pemanenan $\mathrm{Rp} 1.000 / \mathrm{kg}$ dan

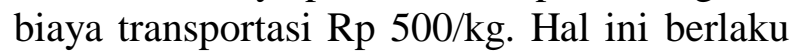
pada sistem penjualan buah dengan cara borongan di atas pohon. Sementara biaya pemasaran pada tingkat pedagang pengecer $\mathrm{Rp}$ 60/kg yang merupakan biaya retribusi pasar.

Berdasarkan rasio keuntungan (Tabel 2), pedagang pengecer mendapatkan keuntungan penjualan paling besar pada setiap saluran pemasaran. Keuntungan pedagang pengecer pada saluran pemasaran 1 , 2 dan 3 secara berturut-turut adalah $\mathrm{Rp}$
$1.440 / \mathrm{kg}, \mathrm{Rp} 1,440 / \mathrm{kg}$ dan Rp 1.940/kg. Hal ini wajar mengingat pedagang pengecer menanggung resiko penurunan harga buah yang besar akibat buah rusak/busuk karena tidak cepat terjual. Sementara itu, pedagang pengepul mendapatkan rasio keuntungan yang lebih kecil dengan resiko yang juga lebih kecil. Pedagang pengepul hanya memindahkan barang dari produsen kepada pedagang pengecer dengan biaya transportasi dan biaya pemanenan. Dengan demikian tidak ada resiko terjadi kerusakan barang karena waktunya cukup singkat. Menurut Ningsih, Felani, \& Sakdiyah (2015), pertimbangan resiko oleh pedagang mempengaruhi besar kecilnya porsi keuntungan pemasaran yang ditetapkan. Selanjutnya Jumiati, Darwanto, \& Hartono (2013) menjelaskan bahwa pada saluran tataniaga yang panjang, rasio keuntungan yang diambil oleh lembaga 
perantara dapat mempengaruhi bagian harga yang diterima produsen karena cenderung semakin besar.

3. Margin pemasaran, farmer's share dan efisiensi pemasaran
Hasil analisis marjin pemasaran buah jamblang dan proporsi harga bagian petani pada kegiatan pemasaran buah jamblang pada masing-masing saluran distribusi disajikan pada Tabel 3 .

Tabel 3. Marjin pemasaran dan proporsi harga bagian petani pada setiap saluran pemasaran buah jamblang Table 3. The margin distribution and proportion of farmer's share for each marketing channel of jamblang fruits

\begin{tabular}{lrrrr}
\hline $\begin{array}{l}\text { Saluran pemasaran } \\
(\text { Marketing chanels })\end{array}$ & $\begin{array}{r}\text { Harga petani } \\
(\text { Farmersprice }) \\
(\mathrm{Rp})\end{array}$ & $\begin{array}{r}\text { Harga konsumen } \\
(\text { Consumers price }) \\
(\mathrm{Rp})\end{array}$ & $\begin{array}{r}\text { Margin Pemasaran } \\
(\text { Marketing margin })\end{array}$ & $\begin{array}{r}\text { Farmer's share } \\
(\mathrm{Rp})\end{array}$ \\
\hline Saluran 1 (Chanel 1) & 1.500 & 6.000 & 4.500 & 25,00 \\
Saluran 2 (Chanel 2) & 3.500 & 6.000 & 2.500 & 58,33 \\
Saluran 3 (Chanel 3) & 3.500 & 6.000 & 2.500 & 58,33 \\
\hline
\end{tabular}

Sumber (Source) : Olah data primer, 2018 (Processed primary data, 2018)

Pada saluran pemasaran 1 margin pemasaran buah jamblang adalah tertinggi $(\mathrm{Rp} 4.500 / \mathrm{kg}$ ) dengan proporsi harga bagian petani (farmer's share) terendah. Pada saluran pemasaran ini, petani memperoleh harga jual buah jamblang Rp 1500/kg. Pada saluran pemasaran 2 dan 3, margin pemasaran adalah sebesar Rp $2.500 / \mathrm{kg}$. Pada saluran 2 dan 3 petani menjual buahnya setelah pemanenan dengan harga $\mathrm{j} R \mathrm{p}$ $3.500 / \mathrm{kg}$. Pada saluran pemasaran 1, 2 dan 3 harga yang dibayarkan konsumen akhir sama yaitu Rp 6.000,/kg.

Farmer's share adalah bagian harga yang diterima petani yang merupakan persentase harga yang diterima dari harga yang dibayarkan oleh konsumen akhir (Angipora, 2002; Herliadi et al., 2015). Untung ruginya para petani tidak ditentukan oleh besar kecilnya nilai farmer's share, tetapi dipengaruhi oleh harga produk dan biaya produksi yang dikeluarkan. Walaupun saluran 2 memiliki rantai pemasaran yang lebih panjang dibanding rantai pemasaran saluran 3 , bagian harga yang diterima petani pada kedua saluran tersebut adalah sama, yaitu $58,33 \%$. Hal ini karena petani mematok harga penjualan yang sama baik kepada pengepul maupun kepada pedagang pengecer $\mathrm{Rp} 3.500 / \mathrm{kg}$ dan harga yang jatuh pada konsumen akhir juga sama Rp 6.000/kg.
Hadirnya lembaga perantara dalam sistem pemasaran tidak selalu merugikan produsen. Terkadang adanya pedagang perantara ini membantu kelancaran distribusi barang dari produsen sampai ke konsumen. Namun apabila rantai pemasaran terlalu panjang akan mempengaruhi pendapatan petani (Husinsyah \& Rasyid, 2017). Selain masalah rantai pemasaran yang panjang, kendala yang umum terjadi pada petani dalam memasarkan produknya adalah kesulitan mengakses informasi pasar (Permadi, 2017). Hal ini terjadi pada petani pemilik pohon jamblang di Desa Triwidadi yang memiliki keterbatasan akses pasar untuk menjual produknya. Oleh karena itu keberadaan pedagang-pedagang perantara menjadi sangat membantu dalam memasarkan buah jamblang.

Sistem pemasaran dapat dikategorikan efisien apabila tercipta keadilan pada kedua belah pihak yaitu produsen dan konsumen (Irawan, 2007); (Muslim \& Darwis, 2012). Produsen mendapatkan harga tinggi dan konsumen mendapatkan harga yang rendah. Kondisi ini dapat terjadi ketika rantai pemasaran tidak terlalu panjang. Pemasaran dikatakan efisien apabila bagian harga yang diterima petani (farmer's share) $>50 \%$ (Soekartawi, 2002). 


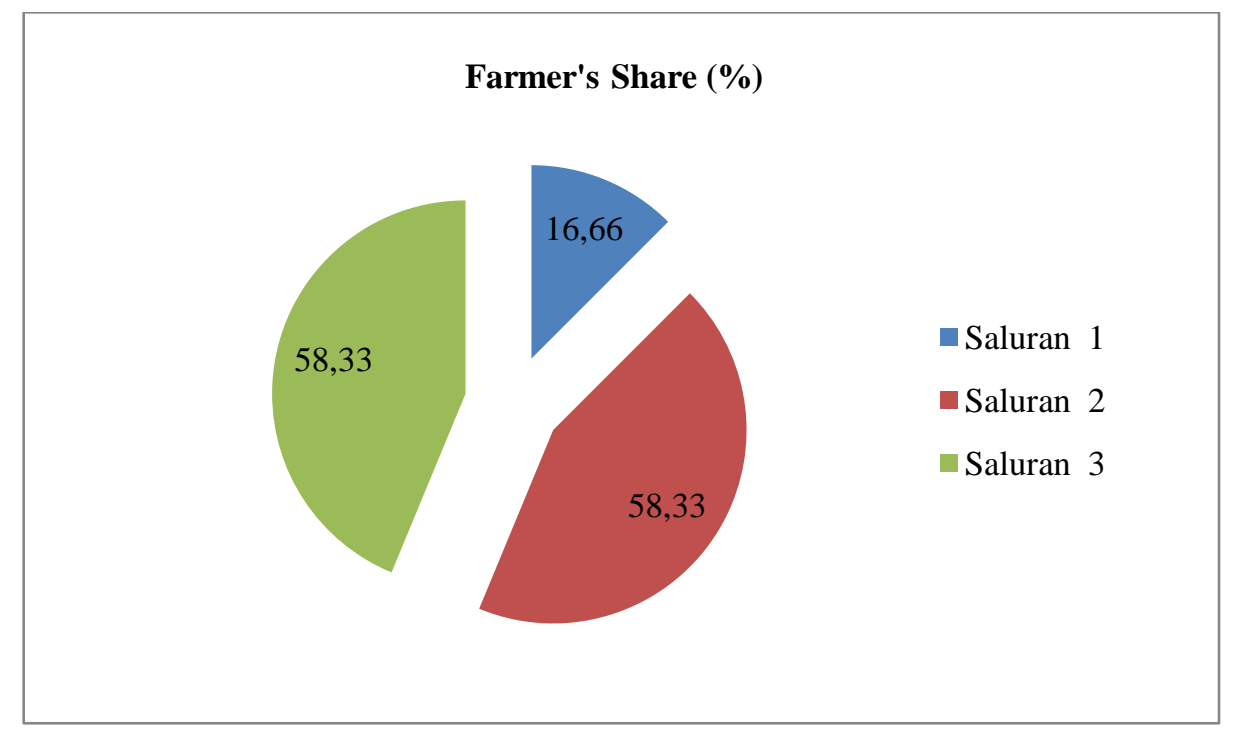

Gambar 3. Proporsi Bagian Harga Petani Dalam Pemasaran Buah Jamblang

Figure 3. Proportion of Farmer's Share for Jamblang Fruits Marketing

Berdasarkan proporsi bagian harga yang diterima petani (Gambar 3), sistem pemasaran buah jamblang pada saluran 1 termasuk kategori tidak efisien karena petani hanya menerima $16,66 \%$ dari harga yang dibayarkan konsumen. Berbeda dengan sistem pemasaran buah jamblang pada saluran 2 dan 3 , petani memperoleh bagian harga sebesar $58,33 \%$. Pada sistem pemasaran ini petani mendapatkan bagian harga $>50 \%$ dari harga yang dibayarkan konsumen. Menurut Hikmah et al. (2015) untuk meningkatkan efisiensi pemasaran dapat diusahakan dengan memperpendek jalur tataniaga dan perbaikan sarana transportasi dengan tujuan untuk menekan biaya pemasaran. Dijelaskan pula oleh Permadi (2017), bahwa peningkatan akses informasi pasar dan sarana tranportasi dalam pemasaran dapat meningkatkan efisiensi pemasaran secara teknis. Secara rinci Erzal, Taslim, \& Masdar (2017) menyebutkan bahwa beberapa faktor yang mempengaruhi efisiensi pemasaran antara lain biaya, keuntungan, jarak tempuh dan sarana prasarana pemasaran.

Ketidakefisienan sistem pemasaran pada saluran 1 lebih disebabkan adanya biaya pemasaran yang lebih besar sehingga margin pemasaran tinggi dan bagian petani yang rendah. Pada saluran 2, biaya pemasaran cukup kecil dibanding saluran 1 sehingga diperoleh farmer's share yang lebih tinggi. Saluran 3 yang memiliki rantai distribusi terpendek dan biaya pemasaran buah jambang lebih kecil dari saluran 2 nilai farmer's share-nya sama dengan saluran 2. Secara teori nilai farmer's share pada saluran 3 seharusnya yang paling besar. Namun hal ini tidak terjadi karena harga penjualan buah jamblang oleh petani kepada baik pengepul dan pengecer adalah sama. Dengan demikian, biaya pemasaran, keuntungan dan marjin pemasaran sangat berpengaruh terhadap besarnya farmer's share.

\section{KESIMPULAN}

Pemasaran buah jamblang di Desa Triwidadi, Kecamatan Pajangan, Kabupaten Bantul terlaksana dengan melibatkan beberapa lembaga pemasaran yaitu produsen/petani, pedagang pengepul, pedagang pengecer dan konsumen akhir melalui tiga saluran pemasaran. Pada saluran pemasaran 1 petani menjual buah jamblang masih diatas pohon kepada pedagang pengepul yang kemudian dijual kepada pedang pengecer sampai ke konsumen akhir. Sementara pada saluran pemasaran 2 petani menjual buah jamblang setelah dipanen 
kepada pedagang pengepul yang kemudian dijual kembali ke pedagang pengecer sampai konsumen akhir. Sedangkan pada saluran pemasaran 3 petani menjual langsung buah jamblang yang telah dipanen kepada pedang pengecer yang kemudian diteruskan ke konsumen akhir. Sistem pemasaran buah jamblang melalui saluran pemasaran 2 dan 3 dinilai lebih efisien dari saluran pemasaran 1 karena memiliki margin yang lebih rendah dan nilai farmer's share $>50 \%$.

\section{UCAPAN TERIMAKASIH}

Ucapan terimakasih disampaikan kepada Balai Penelitian dan Pengembangan Teknologi Agroforestry Kementerian Lingkungan Hidup dan Kehutanan yang telah memfasilitasi terlaksananya kegitan penelitian ini. Terimakasih juga kepada tim penelitian agroforestri jamblang.

\section{DAFTAR PUSTAKA}

Angipora. (2002). Dasar-dasar Pemasaran (Kedua). Jakarta: Raja Grafindo Persada.

Astuti, A. (2014). Analisis Margin Pemasaran Semangka di Daerah Istimewa Yogyakarta. AgroUPY, VI(1), 27-37.

Ayyanar, M., Subash-Babu, P., \& Ignacimuthu, S. (2013). Syzygium cumini (L.) Skeels., A Novel Therapeutic Agent For Diabetes: Folk Medicinal and Pharmacological Evidences. Complementary Therapies in Medicine, 21(3), 232-243.

Chismirina, S., Rezeki, S., \& Rusiwan, Z. (2014). Konsentrasi Hambat dan Bunuh Minimum Ekstrak Buah Jamblang (Syzygium Cumini) Terhadap Pertumbuhan Candida albicans. Cakradonya Dental Journal, 6(1), 655-660.

Dewi, S. R. (2018). Uji Efek Anti Inflamasi Rebusan Daun Jamblang (Syzygium cumini) Pada Mencit (Mus musculus). Media Farmasi, 14(1), 53-59.

Erzal, M. F., Taslim, \& Masdar, A. S. (2017). Analisis Saluran, Margin, dan Efisiensi Pemasaran Itik Lokal Pedaging. Students E-Journal, 5(1), 1-12.

Herliadi, W., Herdiansyah, D., \& Ramdan, M. (2015). Analisis Pemasaran Kapulaga (Studi Kasus Pada Kelompok Tani Cimanggu I di Desa Cimanggu
Kecamatan Langkaplancar Kabupaten Pangandaran). AGROINFO GALUH, 1(3), 197-204.

Hikmah, Nurchayati, \& Ratnawati, A. T. (2015). Pola Pendistribusian Buah Lokal Hasil Produksi di Kota Semarang. In Prosiding Semnas Hasil-hasil Penelitian dan Pengabdian LPPM Universitas Muhammadiyah Purwokerto (pp. 17-23). Purwokerto.

Husinsyah, \& Rasyid, S. (2017). Pengaruh Harga Pasar, Kualitas, Saluran Pemasaran Dan Jarak Lokasi Terhadap Harga Jagung Petani Di Kecamatan Salam Babaris Kabupaten Tapin Propinsi Kalimantan Selatan. Jurnal Scientific, $1(1), 56-62$.

Indrisari, M., \& Zulham, Z. (2018). Antihyperglycemic Activity of Various Extracts of Jamblang (Syzygium cumini) on White Rat. Pharmaceutical and Medicinal Sciences, 2(2), 81-84.

Irawan, B. (2007). Fluktuasi Harga, Transmisi Harga dan Margin Pemasaran Sayuran dan Buah. Analisis Kebijakan Pertanian, 5(4), 358-373.

Istiyanti, E. (2010). Efisiensi Pemasaran Cabai Merah Keriting di Kecamatan Ngemplak Kabupaten Sleman. Mapeta, 12(2), 72-144.

Jumiati, E., Darwanto, D. H., \& Hartono, S. (2013). Analisis Saluran Pemasaran dan Marjin Pemasaran Kelapa dalam di Daerah Perbatasan Kalimantan Timur. Agrifor, 12(1), 1-10.

Kumar, A., Ilavarasan, R., Deecaraman, M., Aravindan, P., Padmanabhan, N., \& Krishan, M. R. V. (2013). Anti-Diabetic Activity of Syzygium cumini and Its Isolated Compound Against Streptozotocin-Induced Diabetic Rats. Journal of Medicinal Plants Research, 2(9), 246249.

Lissa, L., Ratnasari, A., \& Luzyawati, L. (2018). Uji Efektivitas Serbuk Biji Duwet (Syzigium cumini) Sebagai Obat Alternatif Luka Diabetes Mellitus. Gema Wiralodra, 9(1), 43-51.

Mulyana, S., \& Sudomo, A. (2015). Persepsi Masyarakat dan Kelaangkaan Jamblang (Syzygium cumini (L) Skeels) di Kabupaten Majalenggka. In Prosiding Seminar Nasional Agroforestry 2015 "Inovasi Agroforestry Mendukung Kemandirian Bangsa" (pp. 36-43). Bandung.

Muslim, C., \& Darwis, V. (2012). Keragaan Kedelai Nasional dan Analisis Farmer Share Serta Efisiensi Saluran Pemasaran Kedelai di Kabupaten Cianjur. SEPA, 9(1), 1-11. 
Ningsih, K., Felani, H., \& Sakdiyah, H. (2015). Keragaan usahatani dan pemasaran buah naga organik. Agriekonomika, 4(2), 168-184.

Permadi, R. (2017). Analisis Efisiensi Pemasaran Pisang Kepok di Kabupaten Seruyan. UNES Journal of Agricultural Scienties, 1(1), 120-128.

Pradika, A., Hasyim, A. I., \& Soelaiman, A. (2013). Analisis Efisiensi Pemasaran Ubi Jalar di Kabupaten Lampung Tengah. Jurnal Ilmu-Ilmu Agribisnis, 1(1), 25-35.

Rahim, A. (2013). Distribusi dan Margin Pemasaran Ikan Laut Segar Serta Share Nelayan Tradisional. Ekonomi Pembangunan Dan Pertanian, 3(1), 25-39.

Raya, M. K., Ngardita, I. R., \& Sumardi, R. N. (2018). Uji Ekstrak Daun Jamblang (Syzgium cumini L) Terhadap Penurunan Kadar Glukosa Darah Tikus Putih Jantan Yang Diinduksi Streptozotocin. Gema Kesehatan, 10(1), 16-22.

Sami, F. J., Nur, S., Kursia, S., Gani, S. A., \& Sidupa, T. R. (2017). i Aktivitas Antioksidan dari Beberapa Ekstrak Kulit Batang Jamblang (Syzygium cumini) Menggunakan Metode Peredaman Radikal 2, 2-Diphenyl-1Picrylhydrazyl (DPPH). Jurnal Farmasi UIN Alauddin Makassar, 4(4), 130-138.

Sari, F. K. (2013). Formulasi Lipstik Dari Ekstrak
Kulit Buah Duwet (Syzygium Cumini Merr) Sebagai Pewarna Alami Kosmetik Dengan Mengkaji Sifat Fisis Dan Iritasinya. Dissertasi, Universitas Sebelas Maret. Tidak dipublikasikan

Soekartawi. (2002). Analisis Usahatani. Jakarta: UI Press.

Sudarmi, K., Darmayasa, I. B. G., \& Muksi, I. K. (2017). Uji fitokima dan daya hambat ekstrak daun juwet (Syzygium cumini) terhadap pertumbuhan Escherichia coli dan Staphylococcus aureus ATCC. Jurnal Simbiosis, 2(47-51).

Surahman, T., \& Kusnadi, N. (2017). Sistem Pemasaran Nenas Bogor (Ananas comosus) di Kabupaten Bogor. Creative Research Journal, 2(1), 69-82.

Thomson, I. S. I., Anggraini, T., Kurniawan, Y., Yenrina, R., \& Sayuti, K. (2018). Effect of Jamblang (Syzygium cumini) Peel and Citric Acid Addition on Antioxidant Axtivity of Kolang Kaling Jam. Pakistan Journal of Nutrition, 17(3), 140-145.

Widyaningsih, T. W., \& Diniyati, D. (2010). Ekonomi Dan Sistem Pemasaran Hasil Hutan Rakyat Pola Wanafarma di Majenang, Cilacap. Jurnal Penelitian Sosial Dan Ekonomi Kehutanan, 7(1), 55-71. 